\title{
Digital Ecosystem Development Based on Open Innovation Model
}

\author{
Shkarupeta E.V.* \\ Voronezh State Technical University \\ Voronezh, Russia \\ 9056591561@mail.ru
}

Savon D.Yu.

National University of Science and Technology "MISIS"

Moscow, Russia

di199@yandex.ru

\author{
Safronov A.E. \\ Don State Technical University \\ Rostov-on-Don, Russia \\ rgashm@mail.ru \\ Avlasenko L.M. \\ Don State Technical University \\ Rostov-on-Don, Russia \\ avlas333@mail.ru
}

\author{
Kruzhkova G.V. \\ National University of Science and Technology "MISIS" \\ Moscow, Russia \\ g.kruzhkova@misis.ru
}

\begin{abstract}
The article is devoted to the development of theoretical principles and practical recommendations for the formation and development of digital ecosystem based on corporate model of open innovation, which allows adapting an innovative ecosystem to the conditions of global competitive market and integrating it into the global innovation space in order to consolidate competitive advantages and achieve technological superiority. The analysis of Russian and foreign practice of innovative development of technology corporations and companies is performed; practical approaches to managing innovative development of corporations in the context of digitalization are highlighted; methodology for assessing innovative maturity taking into account readiness for digital transformation was developed and tested. The authors proposed methodological approach to classify the tools for corporate governance of open innovations based on analysis of research, technology and innovation ecosystem of a number of Russian and foreign high-tech corporations, characterized by combination of external and internal tools for innovative development with goals, resources and stages of innovative activity, practical implementation cases, which will allow forming optimally scalable and most effective corporate tools from indoor innovations. The study summarizes the existing approaches to the formation and development of digital ecosystem based on the corporate model of open innovation and develops conceptual provisions that provide for the formation of methodological tools for innovation management in order to increase the competitiveness of high-tech industries of Russian Federation, the level of international cooperation and exports, the introduction of digital technologies.
\end{abstract}

Keywords - digital ecosystem, digitalization, industry, open innovations

\section{INTRODUCTION}

Innovation happens when great ideas, people and challenges intersect. In order to develop breakthrough innovations, companies turn to new management models, such as open innovation (collaboration with external partners), design thinking (developing new solutions focused on people's needs), corporate venture funds and incubators $[1,6,10]$ (Fig. 1).

Which of the following approaches, in your opinion, will lead to such innovations that will contribute more to the growth of your company?

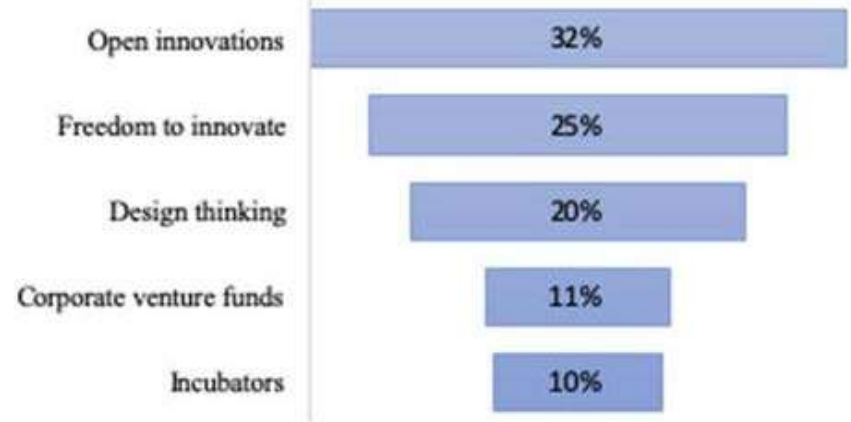

Fig. 1. Companies in the world believe that the open innovation model will lead to the greatest growth (according to materials of PWC, 2019).

By open innovations we mean a model of active interaction of companies with the external environment in the process of innovation with the aim of exchanging technologies, knowledge and competencies, which is realized through the use of the following tools: innovation project competitions, financing of external innovation projects to finalize proposals, corporate accelerators, corporate business incubators, corporate technology parks, corporate venture funds, spin-offs of internal developments, acquisition of companies and others [2, 3].

Industry is on the verge of radical structural changes. Digital transformation carries both huge potential and serious challenges. The study of Roland Berger "Digital 
Transformation of Industry" [4, 5], conducted in conjunction with the German Industry Federation (BDI), examined the causes of digitalization and its impact on industry in Germany and other European countries. The overall economic effect of digitalization was also calculated. In particular, experts found that digitalization of industry until 2025 alone in Germany could create an additional potential for creating value of 425 billion euros. The total figure for Europe is 1.25 trillion euros. If the region fails to turn the transformation into its own advantage, its industry may suffer a total loss in a huge amount of 605 billion euros [7-9].

\section{MethodS AND MATERIALS}

The research methodology is based on existing theoretical developments in the field of innovation management and corporate governance [11]. In the research process, the dialectical approach, system analysis methods, economic and mathematical methods of information analysis, strategic management methods, expert assessments, modeling, clustering, system-activity method, value-oriented, culturalhistorical methods, methods of social constructivism, functional analysis, were used, as well as the prognostic method, etc., which provides a high degree of validity and reliability of the main conclusions and results of study [12].

We have analyzed the Russian and foreign practices of innovative development of technology corporations and companies. The main tool of methodological approach was the research program, which includes the following stages: presentation of problem, goals and objectives of study; research project selection; determination of research methods; collection of information; analysis of information collected [13-15]. To implement methodological approach to classify the tools and practices of corporate governance of open innovation, both desk and field studies were conducted. The sample scope for a survey of company executives ("United Aircraft Corporation" PJSC, "EFKO" group of companies, Rostec) amounted to 30 people. Data collection method - is a questionnaire.

As a result of implementation of methodological approach to classify the tools and practices of corporate governance of open innovation, the tools of corporate open innovation (Table 1) were integrated with the resources for implementing the tool and stages of innovation [16].

The list of tools that corporations can use depends on the stage of innovation and the cost of tools [17, 18]. The largest number of tools is applicable at the stage of searching for ideas, the smallest - at the stage of scaling. If the company doesn't have a significant amount of financial resources, it can use inexpensive tools, for example, events for startups and idea contests. If the company has significant financial resources, it can use tools such as corporate venture fund, laboratories, etc. [19]. As promising areas in the innovative development of corporations, it's possible to single out the use of digital platforms, collaboration and others [20].

$3 \mathrm{M}$ 's ability to keep churning out new innovations is very much dependent on the company's long-standing commitment to open innovation, both internal and external. $3 \mathrm{M}$ has developed organically across consumer, electronic, transportation, industrial, safety, security and display, and electronic markets. The entire technical community at $3 \mathrm{M}$ includes about $10,000 \mathrm{R} \& \mathrm{D}$ people in 73 labs around the world. About 15 to 20 percent of those people work in corporate research, which is responsible for developing, transmitting, and supporting technologies throughout the company. The corporate technical operations committee, or CTOC, ensures the development, health, sustainability, and transmission of 3M's tech capabilities across all the businesses, geographies, and industries in which $3 \mathrm{M}$ operate [28].

TABLE I. CORPORATE OPEN INNOVATION TOOLS

\begin{tabular}{|l|l|}
\hline \multicolumn{1}{|c|}{ Company } & \multicolumn{1}{c|}{$\begin{array}{c}\text { Innovative development tools with a focus on open } \\
\text { innovation }\end{array}$} \\
\hline $3 \mathrm{M}$ & $\begin{array}{l}\text { Unique corporate culture of innovation support; startup } \\
\text { support tools; own developments; mergers and acquisitions; } \\
\text { R\&D financing; technical forum, etc. }\end{array}$ \\
\hline IBM & $\begin{array}{l}\text { Innovation Center, RSTL Laboratory and Science and } \\
\text { Technology Center; blockchain platform; accelerators, etc. }\end{array}$ \\
\hline Airbus & $\begin{array}{l}\text { Innovation centers; global network of aerospace accelerators } \\
\text { Airbus BizLab; venture company Airbus Ventures, etc. }\end{array}$ \\
\hline $\begin{array}{l}\text { "United Aircraft } \\
\text { PJSC }\end{array}$ & $\begin{array}{l}\text { Venture funds; interaction with universities; conducting } \\
\text { hackathons and competitions; creation of corporate sandbox, } \\
\text { etc. }\end{array}$ \\
\hline EFKO & Scouting; startup competition; accelerator; venture fund, etc. \\
\hline Rostec & $\begin{array}{l}\text { Unique technological competency management system; Center } \\
\text { for Open Innovation (COI); additional training courses on the } \\
\text { theory of solving inventive problems (TSIP), etc. }\end{array}$ \\
\hline
\end{tabular}

${ }^{\mathrm{a}}$ Source: drawn up by authors according to materials $[1-10,11,21-27,31-32]$

Airbus makes intersections between great ideas, people and challenges happen by partnering with the outside world to translate innovative ideas into aerospace breakthroughs more quickly than ever before. The way Airbus works with partners is open and agile. This is Airbus approach to accelerating innovation [29].

Innovations are the part of the EFKO's philosophy, and success of the Company was the result of its implementation: in the processing of raw materials, production of high-tech fats and branded products [30]. The research laboratories and centers of applied research are created in all Company's divisions: in the branded division - Service on the new products development; in Fat\&Oil Division - Center for Applied Research and Pilot Facilities, which develops and tests fat products for the lines of healthy food and innovative recipes based on the needs of the food industry manufacturers. In 2013, the company has created Innovation Center "Biruch", and on its basis in 2016 - Innovation Center "Biruch - NT" for solving urgent research problems of existing businesses and for the formation of a reserve of growth drivers. EFKO Group pays special attention to cooperation with leading research institutes, and is actively working with specialized higher education institutions, accelerators of start-up projects and supports the competitions of scientific ideas. EFKO is always looking for new drivers of growth and is interested in supporting of talented professionals with proactive lifestyle, whom it's ready to provide the unique opportunities for selfrealization as a developer of new technologies and innovative projects, and future business leaders based on these projects. 
In the context of general digitalization of socio-economic processes, the company's readiness to transform all processes, or the so-called "innovative maturity" $[33,34]$, comes to the forefront, which is reflected in the system of indicators of methodology for assessing the innovative maturity of companies taking into account readiness for digital transformation.

The digitalization indicators of Russian economy show a greater growth potential compared to the level of Internet penetration. For example, access to digital services in Russia and in the European Union according to a number of indicators: the share of electronic commerce in the total retail volume (Russia $-4 \%$, EU - $7 \%$ ), the share of organizations using CRM systems (Russia - $13 \%$, EU - $26 \%$ ), the proportion of citizens who made purchases online (Russia $29 \%$, EU - $57 \%$ ), the proportion of citizens who received public services via the Internet (Russia - $29 \%$, EU - $48 \%$ ), the penetration of mobile Internet (Russia - $46 \%$, EU $63 \%$ ), smartphone penetration (Russia - $60 \%$, EU - $62 \%$ ), Internet penetration (Russia - $76 \%, \mathrm{EU}-84 \%$ ).

Thus, the Russian Federation has the necessary prerequisites for the active growth of digital economy [35].

State support programs for the development of innovation sector are actively implemented in the Russian Federation. In accordance with Decree of President of the Russian Federation dated May 7, 2018 No. 204, the national program "Digital Economy of Russian Federation" was reformatted by the government of Russian Federation into a national project and cascaded into six federal projects. The total funding will amount to 522 billion rubles ( $\$ 7.8$ billion) $[36,37]$.

The methodology for assessing innovative maturity is designed to conduct independent diagnostics of the current level of innovative maturity of company, determine development directions and identify suitable recommendations for practical application.

The methodology for assessing innovative maturity taking into account readiness for digital transformation includes four stages [38]: assessment of innovative maturity; strategy development and roadmap development; pilot project; scaling. It is proposed to evaluate innovation maturity in seven areas [39]: strategy and aspiration; processes and practices; culture and people; organizational development; openness to external influences; readiness for rapid changes; readiness for digital transformation. For each direction, system of evaluation criteria is proposed, based on the results of expert evaluation of which it's possible to calculate the integral index of innovative maturity, to determine the level and category of maturity of companies and corporations.

The methodology for calculating the final index of innovation maturity is as follows: companies are evaluated by experts on the proposed criteria on a scale of 1 to 10 points, where 10 - the criterion is strongly pronounced; 0 - the criterion is not pronounced. The average of obtained values is the final score. After that, a rating of all respondents is compiled. All participants in the study are divided into quintiles (champions, innovators, followers, observers, opponents) depending on the overall score.

\section{RESULTS}

Testing the methodology for assessing innovation maturity for five companies in 2019 is presented in Table 2.

The first Russian innovative champion ELVEES is a leading Russian ASIC design house - the largest in Russia SpaceWire based chipset developer. ELVEES was founded in 1990 on the ELAS Space Corporation base and in 1960-1980 with RSC "Energia" was a developer of the "Salyut" on-board computers for the "MIR" orbital Space station. ELVEES has its own innovative MULTICORE IC design platform (Standard Cells \& IO \& IP-cores Radiation Tolerant/ temperature stability library), which includes a great CMOS 250-90 nm silicon proven analog, RF and digital IP-cores. The company was responsible for the SpaceWire-RT ASIC IP-core Implementation Feasibility part in the FP 7 RussianEuropean "SpaceWire-RT" project. ELVEES design team has the skills and experience on complex Analog/RF/Digital SoC developments projects under Customer requirements and for the all ASIC Design Flow.

The second Russian innovative champion TechnoSpark creates from scratch, develops and sells companies in a wide range of advanced technological domains: logistic robotics, electric power storage systems, medical high-tech equipment, artificial diamonds, composite materials, optical coatings, genomics, industrial microbiology, thin-film integrated photovoltaics, additive technologies flexible electronics. For TechnoSpark, venture building is a technology for creating high tech businesses two times faster and ten times cheaper than any individual startup entrepreneur. The productivity of TechnoSpark innovation conveyor is intended to save the money and assets of customers, company buyers.

Another Russian innovative champion BIOCAD is leading innovative biotechnology company. The core of BIOCAD business is combining creativity and professionalism in solving problems. Patience and painstaking hard work are the formula for successful achievement of BIOCAD goals. The BIOCAD business is based on the accumulation of advanced knowledge, which enables us to unlock the revolutionary potential for creating optimal conditions for patients to live happier lives. BIOCAD combines a world-class research and development center, ultra-modern pharmaceutical and biotechnological manufacturing facilities, as well as preclinical and clinical research infrastructure compliant with international standards. BIOCAD is one of the worlds few full-cycle drugs development and manufacturing companies, from new molecule discovery and genetic engineering to large-scale commercial production and marketing support. BIOCAD`s medicines are dedicated to treat complex health conditions such as cancer, HIV and Hepatitis C infections, multiple sclerosis and other disorders.

\section{CONCLUSION}

The conclusions should be based on the assessment of differences between the five quintiles of companies. Additionally, a study of large companies was conducted champions of innovative maturity, taking into account readiness for digital transformation [40, 41]. The share of $\mathrm{R} \& \mathrm{D}$ expenditures in the revenue of champion companies was 
on average $16 \%$ for large (with revenues of more than 2 billion rubles), $12 \%$ for medium (revenue from 800 million to 2 billion rubles) and $19 \%$ for small companies (revenue up to 800 million rubles). The share of technological innovation costs in revenue amounted to an average of $23 \%$ for large, $26 \%$ for medium and $25 \%$ for small companies. The share of new products in revenue amounted to an average of $53 \%$ for large, $53 \%$ for medium and $64 \%$ for small companies [41].

TABLE II. TESTING THE METHODOLOGY FOR ASSESSING INNOVATIVE MATURITY ACCORDING TO DATA OF COMPANIES FOR 2019

\begin{tabular}{|c|c|c|c|}
\hline Direction and criteria of assessment & ELVEES & TechnoSpark & BIOCAD \\
\hline 1 Strategy and aspiration & 8.3 & 7.3 & 8.3 \\
\hline 1.1 The degree of influence of innovation on the results of company & 8 & 6 & 8 \\
\hline 1.2 Willingness and ability of company to invest in innovation and take risks & 8 & 7 & 9 \\
\hline 1.3 The role of internal customer in innovation & 9 & 9 & 8 \\
\hline 2 Processes and practices & 7.8 & 8.0 & 7.6 \\
\hline 2.1 Organization of innovation management model & 7 & 7 & 8 \\
\hline 2.2 Organization of project management processes & 8 & 10 & 9 \\
\hline 2.3 The process of approval and decision-making & 7 & 7 & 7 \\
\hline 2.4 The process of piloting and implementing projects & 9 & 7 & 8 \\
\hline 2.5 Availability of innovation tools & 8 & 9 & 6 \\
\hline 3 Culture and people & 7.8 & 8.6 & 7.2 \\
\hline 3.1 Coverage of financial motivation & 8 & 9 & 8 \\
\hline 3.2 The proportionality of financial motivation & 7 & 7 & 6 \\
\hline 3.3 System of key performance indicators (KPI) & 6 & 10 & 7 \\
\hline 3.4 Non-financial motivation & 9 & 8 & 8 \\
\hline 3.5 Culture of experimentation and perception of innovation risks & 9 & 9 & 7 \\
\hline 4 Organizational development & 7.3 & 9.3 & 7.7 \\
\hline 4.1 Focus on customer & 7 & 9 & 7 \\
\hline 4.2 Leadership and involvement of employees & 8 & 10 & 8 \\
\hline 4.3 Introduction of practice transfer tools & 7 & 9 & 8 \\
\hline 4 Openness to external influences & 8.5 & 8 & 7.5 \\
\hline 4.1 Search for new ideas and projects & 8 & 8 & 8 \\
\hline 4.2 Openness to ideas and new opportunities & 9 & 8 & 7 \\
\hline 5 Readiness for rapid changes & 8 & 9 & 7.5 \\
\hline 5.1 Risk acceptance & 7 & 9 & 7 \\
\hline 5.2 Acceptance of innovation by employees & 9 & 9 & 8 \\
\hline 6 Readiness for digital transformation & 9 & 9 & 9 \\
\hline INDEX OF INNOVATION MATURITY & 8.1 & 8.5 & 7.8 \\
\hline Category of innovation maturity & The champion & The champion & The champion \\
\hline
\end{tabular}

Using the recommendations presented, the company can run diagnostics of the current state of innovative maturity and determine the directions for development that will allow moving to the next level of maturity [14]. Depending on the level of innovation maturity, companies should balance between indicators of "actions" related to building the company's potential in the field of innovation (more for beginners) and "results" (more for innovators) [15].

\section{References}

[1] J.H. Gruenhagen, R. Parker, "Factors driving or impeding the diffusion and adoption of innovation in mining: A systematic review of the literature", Resources Policy, vol. 65, 2020. Retrieved from: https://doi.org/10.1016/j.resourpol.2019.101540.

[2] A. Klarin, "Mapping product and service innovation: A bibliometric analysis and a typology", Technol. Forecast. and Soc. Change, vol. 149, 2019. Retrieved from: https://doi.org/10.1016/j.techfore.2019.119776.

[3] J. Trischler, M. Johnson, P. Kristensson, "A service ecosystem perspective on the diffusion of sustainability-oriented user innovations", J. of Busin. Res., 2020. Retrieved from: https://doi.org/10.1016/ j.jbusres.2020.01.011

[4] M. Andersson, O. Moen, P.O. Brett, "The organizational climate for psychological safety: Associations with SMEs' innovation capabilities and innovation performance", J. of Engineer. and Technol. Manag., vol. 55, 2020. Retrieved from: https://doi.org/10.1016/j.jengtecman. 2020.101554
[5] Zh. Zhang, T. Luo, "Network capital, exploitative and exploratory innovations - from the perspective of network dynamics", Technol. Forecast. and Soc. Change, vol. 152, 2020.

[6] X. Cirera, S. Muzi, "Measuring innovation using firm-level surveys: Evidence from developing countries", Res. Policy, vol. 49, no. 3, 2020 Retrieved from: https://doi.org/10.1016/j.respol.2019.103912.

[7] Ch. Kakatkar, V. Bilgram, J. Füller, "Innovation analytics: Leveraging artificial intelligence in the innovation process", Busin. Horizons, vol. 63, no. 2, pp. 171-181, 2020. Retrieved from: https://doi.org/10.1016/j.bushor.2019.10.006.

[8] M. Saunila, "Innovation capability in SMEs: A systematic review of the literature", J. of Innovat. \& Knowledge, 2019. Retrieved from: https://doi.org/10.1016/j.jik.2019.11.002.

[9] H. Ruoslahti, "Complexity in project co-creation of knowledge for innovation", J. of Innovat. \& Knowledge, 2020. Retrieved from: https://doi.org/10.1016/j.jik.2019.12.004.

[10] X. Xie, H. Wang, "How can open innovation ecosystem modes push product innovation forward? An fsQCA analysis", J. of Busin. Res., vol. 108, pp. 29-41, 2020. Retrieved from: https://doi.org/10.1016/ j.jbusres.2019.10.011

[11] Ch.E. De Marco, I. Martelli, A. Di Minin, "European SMEs' engagement in open innovation When the important thing is to win and not just to participate, what should innovation policy do?", Technol. Forecast. and Soc. Change, vol. 152, 2020. Retrieved from: https://doi.org/10.1016/j.techfore.2019.119843.

[12] M. Vidmar, A. Rosiello, N. Vermeulen, R. Williams, J. Dines, "New Space and Agile Innovation: Understanding transition to open innovation by examining innovation networks and moments", Acta 
Astronautica, vol. 167, pp. 122-134, 2020. Retrieved from: https://doi.org/10.1016/j.actaastro.2019.09.029.

[13] T. Tolstykh, D. Savon, A. Safronov, E. Shkarupeta, T. Ivanochkina, "Methods and models for analysis the effectiveness of industrial enterprises", pp. 7710-7722, 2018 [Proc. of the 32nd Int. Business Information Management Association Conf. IBIMA 2018 - Vision 2020: Sustainable Economic Development and Application of Innovation Management from Regional expansion to Global Growth].

[14] T. Tolstykh, D. Savon, A. Safronov, E. Shkarupeta, T. Ivanochkina, "Economic transformations based on competence approach in the digital age”, 2018, pp. 7723-7729 [Proc. of the 32nd Int. Business Information Management Association Conf. IBIMA 2018 - Vision 2020: Sustainable Economic Development and Application of Innovation Management from Regional expansion to Global Growth].

[15] A. Pustovrh, K. Rangus, M. Drnovšek, "The role of open innovation in developing an entrepreneurial support ecosystem", Technol. Forecast. and Soc. Change, vol. 152, 2020. Retrieved from: https://doi.org/10.1016/j.techfore.2019.119892.

[16] N. Sirotkina, E. Syshchikova, M. Filatova, A. Greshonkov, M. Meshcheryakova, "Theoretical and practical provisions of deindustrialization and reindustrialization in Russia”, pp. 8881-8892, 2019 [Proc. of the 33rd Inte. Business Information Management Association Conf. IBIMA 2019: Education Excellence and Innovation Management through Vision 2020].

[17] A. Sivam, T. Dieguez, L. Pinto Ferreira, F.J.G. Silva, "Key settings for successful Open Innovation Arena", J. of Computat. Design and Engineer., vol. 6, no 4, pp. 507-515, 2019. Retrieved from: https://doi.org/10.1016/j.jcde.2019.03.005

[18] Y. Salikov, I. Logunova, I. Kablashova, "Trends in human resource management in the digital economy", Proc. of the Voronezh State Univer. of Engineer. Technol., vol. 81, no. 2, pp. 393-399, 2019. Retrieved from: https://doi.org/10.20914/2310-1202-2019-2-393-399.

[19] N. Serebryakova, I. Avdeev, "The content of structural transformations of the region's economy, adequate to the requirements of digitalization", Proc. of the Voronezh State Univer. of Engineer. Technol., vol. 80, no. 4, pp. 408-412, 2018. Retrieved from: https://doi.org/10.20914/ 2310-1202-2018-4-408-412

[20] A. Rodríguez-Pose, M. Zhang, "The cost of weak institutions for innovation in China", Technol. Forecast. and Soc. Change, vol. 153, 2020. Retrieved from: https://doi.org/10.1016/j.techfore.2020.119937.

[21] D.B. Audretsch, M. Belitski, "The Role of R\&D and Knowledge Spillovers in Innovation and Productivity", Europ. Econ. Rev., 2020. Retrieved from: https://doi.org/10.1016/j.euroecorev.2020.103391.

[22] S. Morkovina, N. Serebryakova, N. Sirotkina, N. Dorokhova, "Labor market regulation policy: Methodological aspects", Europ. Res. Studies J., vol. 21, no. 4, pp. 946-953, 2018.

[23] A. Leckel, S. Veilleux, L. Paul Dana, "Local Open Innovation: A means for public policy to increase collaboration for innovation in SMEs", Technol. Forecast. and Soc. Change, vol. 153, 2020. Retrieved from: https://doi.org/10.1016/j.techfore.2019.119891.

[24] M. Vidmar, A. Rosiello, N. Vermeulen, R. Williams, J. Dines, "New Space and Agile Innovation: Understanding transition to open innovation by examining innovation networks and moments", Acta Astronautica, vol. 167, pp. 122-134, 2020. Retrieved from: https://doi.org/10.1016/j.actaastro.2019.09.029.

[25] J. Räisänen, T. Tuovinen, "Digital innovations in rural microenterprises", J. of Rural Studies, vol. 73, pp. 56-67, 2020. Retrieved from: https://doi.org/10.1016/j.jrurstud.2019.09.010.

[26] J.-Y. Lin, "What affects new venture firm's innovation more in corporate venture capital?", Europ. Manag.t J., 2020. Retrieved from: https://doi.org/10.1016/j.emj.2020.01.004
[27] B. Lin, R. Luan, "Are government subsidies effective in improving innovation efficiency? Based on the research of China's wind power industry", Sci. of The Total Environment, vol. 710, 2020. Retrieved from: https://doi.org/10.1016/j.scitotenv.2019.136339.

[28] S. Szambelan, Y. Jiang, R. Mauer, "Breaking through innovation barriers: Linking effectuation orientation to innovation performance", Europ. Manag. J., 2019. Retrieved from: https://doi.org/10.1016/j.emj.2019.11.001.

[29] F. Henrique Taques, M.G López, L.F Basso, N. Areal, "Indicators used to measure service innovation and manufacturing innovation", J. of Innovat. \& Knowledge, 2020. Retrieved from: https://doi.org/10.1016/j.jik.2019.12.001.

[30] M. Zheng, G.-F. Feng, S. Feng, X. Yuan, "The road to innovation vs. the role of globalization: A dynamic quantile investigation", Econ. Modell., vol. 83, pp. 65-83, 2019. Retrieved from: https://doi.org/10.1016/j.econmod.2019.09.019.

[31] N. Sirotkina, V. Mishchenko, A. Greshonkov, S. Kaminskiy, A. Kazartseva, "Challenges and opportunities of human potential in the conditions of technological breakthrough", pp. 7910-7918, 2019 [Proc. of the 33rd Int. Business Information Management Association Conf., IBIMA 2019: Education Excellence and Innovation Management through Vision 2020]

[32] D. Loorbach, J. Wittmayer, F. Avelino, T. von Wirth, N. Frantzeskaki, "Transformative innovation and translocal diffusion", Environmental Innovat. and Societal Transitions, 2020. Retrieved from: https://doi.org/10.1016/j.eist.2020.01.009.

[33] L. Chai, J. Li, Ch. Tangpong, T. Clauss, "The interplays of coopetition, conflicts, trust, and efficiency process innovation in vertical B2B relationships", Industrial Market. Manag., 2019. Retrieved from: https://doi.org/10.1016/j.indmarman.2019.11.004.

[34] M. Cucculelli, V. Peruzzi, "Innovation over the industry life-cycle. Does ownership matter?", Research Policy, vol. 49, no. 1, 2020. Retrieved from: https://doi.org/10.1016/j.respol.2019.103878.

[35] O. Belenov, S. Kiselev, N. Sirotkina, M. Titova, "Transformation of the Regional Innovation Sub-system as a Factor in the Development of the Digital Economy", Lecture Notes in Networks and Syst., vol. 87, pp. $482-488,2020$.

[36] N. Sirotkina, O. Stukalo, N. Nikitina, M. Filatova, "Crises and digital economy: The territorial aspect of the problem of networking of stakeholders in the food markets", Advan. in Intellig. Syst. and Comput., vol. 908, pp. 686-692, 2020.

[37] N. Sirotkina, O. Stukalo, N. Nikitina, A. Chudaeva, "Networks of competences of subjects of the local food market in the conditions of formation of digital economy", Advan. in Intellig. Syst. and Comput., vol. 908, pp. 419-425, 2020

[38] E. Kolesnichenko, S. Morkovina, N. Sirotkina, A. Shevyakov, "Tendencies of the development of forest management in modern Russia", IOP Conf. Ser. Earth and Environmental Sci., 2019.

[39] N. Klunko, N. Sirotkina, O. Krasnonosova, "Strategic management in pharmaceutics development under world economic globalization transformations", J. of Environmental Treatment Techniques, vol. 7, no. 3, pp. 409-417, 2019.

[40] N. Sirotkina, E. Syshchikova, M. Filatova, A. Greshonkov, M. Meshcheryakova, "Directions of the transformation of companies and universities in the digital economy”, pp. 8970-8975, 2019 [Proc. of the 33rd Int. Business Information Management Association Conf., IBIMA 2019: Education Excellence and Innovation Management through Vision 2020].

[41] A. Bogoviz, Y. Ragulina, N. Sirotkina, "Systemic contradictions in development of modern russia's industry in the conditions of establishment of knowledge economy", Advan. in Intellig.t Syst. and Comput., vol. 622, pp. 597-602, 2018. 